\title{
Extracorporeal Photochemotherapy as a Challenging Treatment for Cutaneous T-Cell Lymphoma, Acute and Chronic Graft-versus-Host Disease, Organ Rejection and T-Lymphocyte-Mediated Autoimmune Diseases
}

\author{
Paolo Perseghin \\ U.O.S. Aferesi e nuove tecnologie trasfusionali-Laboratorio di criobiologia, Dipartimento di Patologia Clinica-Servizio di \\ immunoematologia e Trasfusionale, Ospedale San Gerardo de' Tintori, Monza, Italy
}

\begin{abstract}
Key Words
Extracorporeal photochemotherapy - Photopheresis . Graft-versus-host disease - Cutaneous T-cell lymphoma . Autoimmune diseases
\end{abstract}

\section{Summary}

20 years ago, in 1987, Edelson and co-workers published their first report on the effectiveness of a new procedure, called extracorporeal photochemotherapy (ECP), in patients with advanced stage cutaneous T-cell lymphoma (CTCL). The positive response ( $>70 \%$ overall) achieved in those patients encouraged several groups to try out this new technology in other T-lymphocyte-mediated autoimmune diseases and a number of dermatological diseases, which sometimes gave conflicting results. In the following years, ECP obtained FDA approval as first line treatment in CTCL. In the 1990s ECP was applied to acute and chronic graft-versus-host disease (GvHD) refractory to conventional immunosuppressive therapy and proved to be effective in $>60 \%$ of cases of this larger patient population. Today, although the effectiveness of ECP in GvHD is generally acknowledged, this is mainly based on retrospective or observational studies, as data from large, randomized multicenter trials, has yet to be published. Moreover, ECP's real mechanism of action and optimal treatment schedule are still under investigation. The aim of this review is to summarize knowledge acquired to date about ECP.

\author{
Schlüsselwörter \\ Extrakorporale Phototherapie · Photopherese - Graft- \\ versus-Host-Erkrankung · Kutanes T-Zell-Lymphom . \\ Autoimmunkrankheiten
}

\section{Zusammenfassung}

Vor 20 Jahren berichteten Edelson und Mitarbeiter erstmals über die erfolgreiche Photopherese bei Patienten mit fortgeschrittenem kutanem T-Zell-Lymphom (CTCL). Die hohe Ansprechrate ( $>70 \%$ insgesamt) nach Photopherese bei CTCL ermutigte verschiedene Forschergruppen, diese neue Technologie bei anderen T-Lymphozyten-vermittelten Autoimmunkrankheiten und dermatologischen Erkrankungen anzuwenden. Die Ansprechraten bei diesen Erkrankungen waren unterschiedlich und widersprüchlich. Mittlerweile wurde die Photopherese als First-line-Behandlung bei der CTCL von der amerikanischen FDA zugelassen. In den 1990er Jahren wurden die Photopherese bei Patienten mit akuter und chronischer Graft-versus-Host-Erkrankung, die nicht auf eine konventionelle immunsuppressive Therapie ansprachen, angewendet und erfolgreich in mehr als $60 \%$ der Fälle bei dieser großen Patientenpopulation eingesetzt. Heutzutage ist die Effektivität der Photopherese bei der Graftversus-Host-Erkrankung allgemein anerkannt, die Daten beruhen jedoch hauptsächlich auf retrospektiven Analysen oder Beobachtungsstudien. Ergebnisse von großen, randomisierten multizentrischen Studien hierzu müssen noch veröffentlicht werden. Der Wirkmechanismus der Photopherese und das optimale Behandlungsregime sind noch unter klinischer Erprobung. Diese Übersichtsarbeit fasst unser gegenwärtiges Wissen über die Photopherese zusammen.

\begin{tabular}{ll}
\hline KARGER & @ 2008 S. Karger GmbH, Freiburg \\
Fax +497614520714 & Accessible online at: \\
$\begin{array}{l}\text { E-mail Information@Karger.de } \\
\text { www.karger.com }\end{array}$ & www.karger.com/tmh
\end{tabular}




\section{Foreword}

By searching the Pubmed database (end of June 2007) and using 'extracorporeal photochemotherapy' and/or 'photopheresis' as key words, a total of 654 references were found. This suggests the growing popularity of this therapeutic procedure in several clinical settings since the pioneering paper by Edelson et al. [1] was published in the late 1980s, describing the effectiveness of extracorporeal photochemotherapy (ECP) in treating cutaneous T-cell lymphoma (CTCL) patients, refractory to conventional treatments.

\section{Historical Background}

In 1974, Parrish et al. [2] reported on the efficacy of skin ultraviolet A (UVA) irradiation following oral administration of psoralen in patients with psoriasis. This observation led Edelson and co-workers to develop a system to treat patients with CTCL. These authors observed that ECP induced full remission of the disease in several patients and a substantial reduction of the skin involvement in others. Moreover, an increased survival was observed in ECP-treated patients when compared to controls (median 60 vs. 30 months) [3]. In the following years, ECP was tentatively adopted in several autoimmune T-cell-mediated diseases such as pemphigus vulgaris [4], systemic sclerosis [5], psoriatic arthritis [6], rheumatoid arthritis [7], Crohn's disease [8] and multiple sclerosis [9]. Furthermore, ECP was also introduced in the treatment of organ rejection [10] and in the treatment of both acute and chronic graft-versus-host disease (GvHD) refractory to conventional immunosuppressive therapy in patients who had previously undergone bone marrow transplantation [11]. To date ECP is performed in about 200 centers worldwide, and the number of procedures is continuously increasing. Nevertheless, in spite of an increasing number of published reports describing its effectiveness in several clinical settings, there is still a lack of large, randomized multicenter studies which aim to ascertain its real efficacy in different diseases. The purpose of this review, is to focus on technical and practical issues related to ECP, its putative mechanism(s) of action, and finally on its possible applications in the clinical setting.

\section{Devices and Techniques}

ECP mainly consists of three subsequent steps: 1) collection of mononuclear cells (MNC), 2) irradiation of MNC in the presence of 8-methoxypsoralen (8-MOP) by means of UVA at 320-400 nm wavelength, and finally 3) infusion of irradiated MNC to the patient over 30-40 min [12]. MNC collection was initially performed by means of a single vein discontinuous flow cell separator developed by Therakos (UVAR) which, in spite of the use of a $120 \mathrm{ml}$ pediatric bowl, was not suitable for patients with low body weight $(<40 \mathrm{~kg})$. The whole procedure consisted of six collection cycles, during which buffy coat was collected and irradiated (at $2 \mathrm{~J} / \mathrm{cm}^{2}$ ) within a special chamber integrated in the same apparatus. In the very first experience performed by Edelson et al. [1], 8-MOP was orally administered to the patient at $0.6 \mathrm{mg} / \mathrm{kg} \mathrm{BW}$ at least $1-2 \mathrm{~h}$ prior to MNC collection. This approach was flawed by the variable absorption of the drug in different patients and by the onset of side effects such as nausea and vomiting, induced by 8-MOP ingestion. Over recent years, new formulations suitable for i.v. administration have become available (UVADEX from Therakos and EC-8-MOP from Gerot Pharmaceutical), to be added at lower concentration $(200 \mathrm{ng} / \mathrm{ml})$ to the MNC collection bag before irradiation. This has allowed for both a more standardized use of the photoactivable drug and a reduced incidence of drug-related side effects in the patients. In 1994, Andreu et al. [13] in France proposed a modification to the ECP procedure: the first step was accomplished using a continuous flow cell separator (Gambro Spectra), then 8-MOP at $200 \mathrm{ng} / \mathrm{ml}$ final concentration was added to the MNC in an external plastic bag (Macopharma), and the product was finally irradiated using an ad hoc device (UV-Matic; Vilber-Lourmat) before re-infusion into the patient. This method was defined as the 'off-line' technique, compared to the 'on-line' technique proposed by Therakos (which later went on to develop a new version of the original device: the fully automated discontinuous flow UVAR ${ }^{\circledR}$ XTS $^{\mathrm{TM}}$ machine, equipped with either a 120 or $225 \mathrm{ml}$ bowl, presently on the market). The off-line method became very popular, especially in Europe, as the very low extracorporeal volume which is enabled by the use of continuous flow cell separators, allows to easily and safely adopt this procedure even in low-weight pediatric patients [14, 15]. Furthermore, this method allows for high product purity in terms of MNC content and for a final hematocrit below $2 \%$ which is particularly important given that higher hematocrit values may intercept UVA and thus compromise irradiation efficacy. It should be pointed out that the volume of the collected product is usually higher with the Therakos devices (from $280 \mathrm{ml}$ with the UVAR XTS to $540 \mathrm{ml}$ obtained with the former version UVAR, compared to 50-150 ml obtained with the off-line methods $[12,17]$. Moreover, the off-line method allowed for performing very accurate quality controls on the total number of collected MNC and their differential count, which might in turn be of relevance from a clinical point of view [16, 17]. For clarity's sake, it should be said that when ECP is performed with the on-line method, the collected buffy coat is pumped through the irradiation chamber, allowing for closer contact of the MNC with the plastic devices; it is possible that the rolling of monocytes on the artificial material may facilitate their switch to dendritic cells, which may account (at least in part) for ECP's mechanism of action. When the off-line method is adopted, the collected cells undergo irradiation in a plastic bag, under mild agitation, on a flat surface at constant temperature. The on-line method is currently FDA-approved 
as first line treatment for CTCL and is a completely closed system while the off-line method requires manual transfer of the collected cells into the irradiation bag and, even if these steps can be performed in a laminar flow cabinet and/or by using a sterile connecting device, a residual risk of contamination still remains. To date no randomized studies have been performed aimed at comparing on-line and off-line techniques and treatment schedule. This latter point will be discussed in another part of this review.

Finally, taking into account European Community regulations about medical devices, new machines (all CE marked) have been progressively introduced into practice, such as the recently released UVA irradiator Macogenic from Macopharma, which allows for a full traceability of the irradiation procedure, and the UVA Photo Immune Therapy (PIT) System from Med Tech Solutions [18]. Several validation studies are currently being performed on these devices, and Therakos itself is currently developing a continuous flow cell separator with lower extracorporeal blood volume, to make it suitable for the treatment of low-weight patients. Up to now, only limited information is available on the above described devices in the form of abstracts or oral presentations, and will therefore not be quoted in this review.

\section{Treatment Schedule}

Treatment schedule may vary from center to center and may be different for different diseases. In CTCL patients, on the basis of Edelson's group experience, two ECP procedures are administered monthly and continued without any pre-fixed time limit on the basis of clinical response [1]. In both acute and chronic GvHD patients two ECPs are performed on consecutive days for 3-4 weeks, followed by two ECPs fortnightly and finally by two ECP/month, for a total of at least 6 months or 20 ECP [16, 17]. Different schedules have been reported in other clinical settings and will be detailed afterwards in the text.

\section{The Putative Mechanisms of Action of ECP}

The real mechanisms of action by which ECP exerts its effects are still not well understood although several papers aimed at elucidating this issue have been published over the last years. Many changes have been shown to happen to MNC during ECP procedures. Some effects might be related to the close contact between the cells and the artificial plastic surface (the so-called 'rolling' mechanism) during both the collection step within the cell separator and the subsequent contact within the irradiation chamber (in the on-line method) or the plastic bag used in the off-line method. It has been shown that contact with artificial surfaces may enhance the transformation of monocytes into dendritic cells [19,20]. The further addition of the photoactivable drug 8-MOP and the subsequent irradia-
Table 1. ECPinduced cytokines production changes in lymphocytes and monocytes

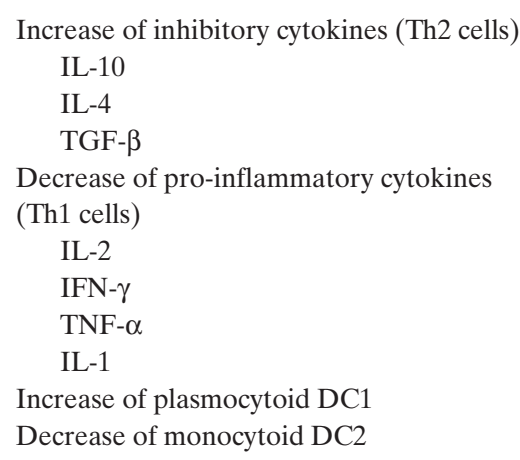

tion by means of 320-400 nm wavelength UVA, lead to several cellular modifications, including cell membrane damage and antigen modification, irreversible cross-linking between 8MOP and DNA (with this effect being maximal at $350 \mathrm{~nm}$ wavelength) as well as the formation of covalent bindings with several cytosolic proteins and fatty acids [13, 20,21].

\section{ECP-Induced Changes in Cytokine Production}

All mechanisms described above may induce apoptosis in treated cells, becoming apparent by the appearance of specific markers on the cell surface such as the externalization of the early marker phosphatidylserine that could be identified by Annexin $\mathrm{V}$ [22]. In vivo and in vitro studies performed on ECP-treated MNC showed that lymphocytes are more prone to undergo apoptosis than monocytes [23] and that ECP may induce a down-regulation of pro-inflammatory cytokine production, mainly in untreated monocytes. These latter findings might be of clinical relevance in some diseases such as GvHD in which pro-inflammatory cytokines such as TNF- $\alpha$, IFN- $\gamma$, and IL-2 are considered to play an important pathogenetic role in the onset and severity of acute GvHD [20, 22-27]. To better ascertain the possible mechanism of action of ECP on the immune system, a new device has recently been developed to investigate ECP activity on small volumes of blood, thus mimicking what happens during a real ECP procedure performed on patients [28].

Most relevant changes in cytokine production which may arise after ECP procedures are listed in table 1.

\section{ECP-Induced Changes in Cellular Immunity and Importance of Tolerogenic Cells}

ECP-induced apoptosis is believed to play an important role in re-modulating immune response in treated patients even if its mechanism of action may be different in different diseases [20]. ECP may induce an anti-idiotype response to clonal T-cell population damaged by UVA treatment in clonal diseases such as CTCL [29]; apoptotic lymphocytes may be re- 
sponsible for cytokine secretion, thus inducing modifications in immune response, and may be phagocytozed by immature dendritic cells arising from monocyte activation and switch induced by ECP [20, 29, 30]. In fact, ECP may induce the differentiation of monocytes into CD83+ CD36+ immature dendritic cells with strong phagocytic activity which may act as antigen-presenting cells (APC) and take up apoptotic cells [31], thus triggering a specific cell-mediated immunologic response against a specific cellular population. In CTCL patients who have a clonal disease represented by CD4+ lymphocyte with Th1 profile a normalization of CD4/CD8 ratio together with a shift from Th1 to Th2 cytokine secretion has been observed, with a subsequent reduction of IL-12 production which may in turn reduce the clinical manifestation of CTCL [29, 32, 33].

A different mechanism of action of ECP may be implicated in acute and chronic GvHD, because of the different pathogenesis of the disease. Acute GvHD is a T-cell-mediated complication which may occur after hematopoietic stem cell transplantation (HSCT) when donor-derived T cells are stimulated by host APC, with the enhancement of several pro-inflammatory cytokines such as TNF- $\alpha$, IL-1, IL- 6 and IL-8, thus configuring a predominant Th1 immune response [20,34]. Chronic GvHD might be considered as an autoimmune disease with a predominant Th2 response, irrespective of whether it follows a previous acute GvHD or arises at more than 100 days from HSCT. The onset of autoreactive T-cell clones and a contemporary impairment and/or decrease of T-regulatory lymphocytes (T-reg) with a CD4+ CD25+ phenotype at high fluorescence intensity are of paramount importance in the pathogenesis of this form of GvHD [35-38]. It has been observed that ECP may induce a shift from Th1 to Th2 response, thus reducing the secretion of proinflammatory cytokines, and a contemporary shift from DC1 (plasmocytoid) to DC2 (monocytoid) cell type $[39,40]$, suggesting that ECP may act by altering alloreactivity by both modulating allotargeted effector $\mathrm{T}$ cells and dendritic APC.

Recently, some research teams published details on the ECPinduced increase of T-regs in patients treated for organ transplant rejection or for acute or chronic GvHD. In 4 children treated with ECP for heart or lung rejection, Lamioni et al. [41] observed a significant increase of T-regs compared to children who were treated with conventional immunosuppressive therapy; moreover, these authors observed that T- and B-cell response to novel or recall antigens were conserved in patients treated with ECP, but not in the control patients. Biagi et al. [42] evaluated 10 patients (4 acute and 6 chronic GvHD), all undergoing ECP for refractory GvHD. All 10 patients responded to the treatment, and in all cases ECP was accompanied by an increase of T-regs after six procedures (from 8.9 to $29 \%$ of total CD4+ lymphocytes). T-regs expressed high levels of CD62L, CD45RO and Fox P3 antigens. Furthermore, sorted CD4+ CD25+ fractions were strongly inhibitory towards CD4+ CD25- fractions when stimulated with allogeneic cells in trans-well experiments.
Table 2. Therapeutic applications of ECP (only main reference to clinical reports are shown)

\begin{tabular}{ll}
\hline Disease & References \\
\hline T-cell lymphoma & $1,3,21,32,43-47$ \\
(Sezary syndrome, mycosis fungoides) & \\
Pemphigus bullosus (vulgaris) & $4,48,49$ \\
Atopic dermatitis & 53 \\
Psoriatic arthritis & $2,6,79,80$ \\
Lichen planus & 52 \\
Epidermolysis bullosa & 50,51 \\
Organ rejection (heart, lung, kidney, liver) & $10,91-101$ \\
Progressive systemic sclerosis & $5,73-76$ \\
Systemic lupus erythematosus & 81 \\
Rheumatoid arthritis & 77,78 \\
Acute and chronic GvHD & $11,14-17,29,54-72$ \\
Chrohn's disease & 8 \\
Multiple sclerosis & $9,82,84,85,88$ \\
Treatment of malignancy (transimmunization) & $19,102-105$ \\
\hline
\end{tabular}

\section{ECP in the Field}

Since its first application in patients with CTCL the effectiveness of ECP has been investigated in a number of different clinical settings, sometimes with conflicting results (table 2). Unfortunately, most papers published so far report on single center, small patient series, evaluated in non-randomized studies. To date, ECP has obtained FDA approval as a treatment of proven efficacy only in CTCL patients. The most significant findings achieved in different diseases are reported below.

\section{CTCL and Other Dermatological Diseases}

\section{CTCL}

In their first paper reporting on the efficacy of ECP in CTCL, Edelson et al. [1] showed that $73 \%$ of 37 patients ( 29 with erythrodermic stage of the disease) had a greater than $25 \%$ improvement of the skin score, with $24 \%$ of the patients showing a $75 \%$ decreased skin score. In patients with erythroderma, they observed $83 \%$ of clinical responsiveness, compared to just $38 \%$ in those individuals with plaques or tumors. Complete clinical remission was observed in 6 patients and lasted 5-7 years [43]. Similar results were achieved by Crovetti et al. [44] on 30 evaluable patients, with a favorable clinical response in 16/21 (81\%) patients with mycosis fungoides and in 6/9 (66\%) patients with Sézary syndrome [44]. In 2001 Evans et al. [45] investigated possible parameters as predictors of response in CTCL patients undergoing ECP (two ECP/month for 6 consecutive months). They found that patients with a higher baseline Sézary cell count were more likely to respond to ECP after a 6-month treatment than those with lower values. These findings favored the hypothesis that a minimum tumor burden was required for the induction of a cytotoxic re- 
sponse [45]. In 2003 Knobler and Jantschitsch [46] analyzed data on 448 patients with CTCL treated with ECP reported in 17 published papers, with an overall response rate of $61 \%$. Some parameters were identified from the evaluated papers as predictors of responsiveness, such as duration of the disease $<2$ years, no bulky adenopathy or major organ involvement, presence of discrete number of Sézary cells (as quoted in [45]), absence of prior intensive chemotherapy, and plaque stage disease at not more than $10-15 \%$ of total skin surface. In all quoted studies, ECP was performed using the on-line method during which about $5-10 \%$ of the total circulating $\mathrm{T}$ cells were collected and treated.

In 2005 Schreiner et al. [47] reported on 3 patients with endstage CTCL (2 mycosis fungoides) not eligible for ECP, in whom a so-called 'small-scale ECP' was performed. Briefly, they collected MNC from $50 \mathrm{ml}$ of whole blood, and after density gradient centrifugation the cells were UVA-irradiated in presence of 8-MOP. The treatments were conducted 2-3 times a week (for a total of 5,10 and 27 treatments in the 3 patients). Both patients with mycosis fungoides showed a prompt response to the treatment [47]. This last paper opened several questions on the number of cells to be treated and the frequency of the treatment and whether apheresis technology could be circumvented, at least in selected patients.

\section{Other Dermatological Diseases}

ECP treatment has been proposed in several autoimmune dermatological diseases, including pemphigus bullosus and vulgaris, in drug-resistant patients or as an adjuvant therapy [48-50], with satisfactory results in $60-75 \%$ of patients. Similar findings regarding ECP treatment have been published in epidermolysis bullosa [51], chronic erosive lichen planus [52] and atopic dermatitis [53]. Unfortunately, the authors only reported on single-center, small non-randomized patients series. Thus, the beneficial effect of ECP in the above reported dermatological disease should be investigated in larger patient series and in randomized multicenter studies.

\section{Acute and Chronic GvHD}

GvHD still accounts for a high proportion of morbidity and mortality following allogeneic HSCT, irrespective of immunosuppressive treatment and better donor selection by means of molecular biology methods. Acute GvHD may occur in up to $40 \%$ of transplanted patients who receive stem cells from a fully matched familiar donor, and in up to $70 \%$ of those who receive stem cells from a matched unrelated donor [34, 35, 54, 55]. Since the mid 1990s, several authors have reported on the effectiveness of ECP in the treatment of acute and chronic GvHD refractory to conventional immunosuppressive therapy [56-58]. In 1998 Greinix et al. [59] reported on 21 patients with GvHD unresponsive to conventional therapy, including steroids. Six patients had acute grade II-III GvHD, and 15 pa- tients had extensive chronic GvHD. Greinix et al. observed that acute GvHD resolved completely in $67 \%$ of patients and partially in the remaining $33 \%$ after a median of 14 ECPs. Oral mucosal ulcerations resolved in all patients, and cutaneous chronic GvHD completely resolved in $80 \%$ of patients. Seven out of 10 patients with chronic GvHD and liver involvement showed a complete response. No severe infections were observed, neither during ECP treatment nor after discontinuation. In 2000 Sniecinski et al. [60] reviewed previously published data on 40 and 154 patients with acute and chronic GvHD, respectively, treated at different institutions with very different treatment schedules. The procedures were well tolerated, and side effects (evaluated in 2,172 ECPs performed in 95 patients) were minimal (1.29-1.93\%), consisting mostly of nausea, chills, increased transfusion requirements (red blood cells and platelets), and catheter malfunction/catheter infection. In chronic GvHD patients the response rate was 88,80 , 81,44 and $33 \%$ in gastrointestinal tract, liver, skin, mucosal and lung involvement, respectively. Responsiveness in acute GvHD patients was 89,60 and $42 \%$ in skin, gastrointestinal tract and liver, respectively. ECP did not increase the infection rate. Another important, beneficial effect of the treatment was the tapering or discontinuation of immunosuppressive drugs, mainly steroids, in responsive patients. In the following years several groups worldwide reported on the effectiveness of ECP in both adults and children with acute or chronic GvHD, treated with either the on-line or off-line ECP techniques [14, 16, 29, 61-63].

ECP proved to be effective even in the treatment of long-lasting ( $>6$ years) chronic GvHD [64]. It should be emphasized that, even though there was a substantial overlap in terms of overall responsiveness to ECP when patient series from different institutions were evaluated, it was still quite difficult to compare achievements due to heterogeneous inclusion criteria and diverse patient stratification. These difficulties might arise from the lack of reproducibility of the GvHD grading system (mainly in chronic GvHD) in different groups. Consequently, new clinical grading systems aimed at identifying prognostic parameters as well as new criteria for evaluating responsiveness have been proposed in these last years [65-67]. In 2005 Foss et al. [68] published the results of a prospective study performed on 25 patients with high-risk chronic GvHD following Akpek's criteria [65]. The authors did not observe any difference between a favorable (Akpek score $<2.5$ ) or unfavorable (Akpek score $>2.5$ ) risk group, but patients with progressive onset chronic GvHD showed a better response rate when compared to those with de novo chronic GvHD (78 vs. $50 \%$ ). Furthermore, the response rate was similar in patients who received weekly ECP compared to those who received ECP every 2 weeks. However, in 2006 Couriel et al. [69] observed a trend towards a higher response rate in patients with de novo chronic GvHD in a retrospective study performed on 71 patients with steroid-resistant chronic GvHD. There were 6 nonrelapse deaths in 17 patients with de novo chronic GvHD 
compared to 8 non-relapse deaths which occurred in 16 patients with progressive chronic GvHD $(p<0.4)$. In the same study, thrombocytopenia (platelets $<100,000 / \mathrm{mm}^{3}$ ) at time of starting ECP treatment was significantly associated with a lower response rate [69].

Garban et al. [70] reported on 27 patients (12 acute GvHD) treated with intensified ECP (six courses in 3 weeks), with a satisfactory response rate (9/12 patients with acute and 13/15 patients with chronic GvHD). Similar results were reported in 2006 by Greinix et al. [71] in 59 patients. 21 patients received ECP at weekly intervals for 3-4 weeks, then every 2-4 weeks, while 38 patients received ECP weekly until maximal response. The authors observed that the probability of survival was $59 \%$ among patients who responded completely to ECP compared to just $11 \%$ in non-responders.

In a retrospective study published in 2007,25 patients with chronic GvHD were evaluated to find out if the number of collected and treated MNC could influence response to ECP treatment [17]. The analysis of the cell dose suggested that an increase in MNC dose $/ \mathrm{kg} \mathrm{BW}$ induced a decrease in the odds of treatment failure and that, if a cell dose of at least $100 \times 10^{6} / \mathrm{kg} \mathrm{BW}$ per ECP treatment was administered, a more positive and long-lasting response was achieved. Nevertheless, while intriguing, these findings have yet to be confirmed in larger patient series and in randomized multicenter studies.

Finally, it has been suggested that ECP might play a role in preventing GvHD if administered before hematopoietic stem cell infusion, with the aim of modulating the activity of host APC [72].

\section{Miscellaneous Autoimmune Diseases}

A few years after the paper of Edelson et al. [1] on CTCL, Rook et al. [73] reported on a favorable response observed in 2 patients with advanced-stage systemic sclerosis, an autoimmune disease characterized by a generalized deposition of collagen within tissues and organs and by a CD4+ T lymphocyte infiltration of the skin, showing progressive functional limitations and limited survival (20\% at 10 years). The same authors set up a clinical trial which aimed to compare patients randomly given D-penicillamine or ECP (two procedures/month for 6 months). 79 patients were evaluated, and the overall response (improvement in skin thickening and decrease in dermal collagen deposition) was 68 vs. $32 \%(p=0.002)$ when ECP patients were compared to those who received D-penicillamine [74]. These findings could not be confirmed by Zachariae et al. [75] in a study performed on 8 patients with progressive systemic sclerosis. However, Knobler et al. [76] very recently demonstrated the effectiveness of ECP in a 16-center, randomized, doubleblind placebo-controlled trial performed on 64 patients with disease duration $<2$ years. The authors observed a significant improvement in skin scores $(p=0.0024)$ in patients who underwent ECP compared to those who underwent sham apheresis. The different results obtained in the last quoted papers (whilst considering that the number of evaluated patients is quite different: 8 vs. 64) might largely depend on different patient selection criteria. Several papers, mostly published in the mid 1990s, reported on the effectiveness of ECP in other autoimmune diseases such as rheumatoid arthritis, psoriatic arthritis, systemic lupus erythematosus (SLE) and Crohn's disease [8,77-81], but these papers anecdotically reported on single-center, small patients series or single-case reports and were not followed by further studies. Based on the evidence that multiple sclerosis is a T-cell-mediated disease [82] and that T cells treated with ECP were not able to induce experimental allergic encephalomyelitis in an accepted animal model of multiple sclerosis [83], Poehlau et al. [84] treated 2 patients with a relapsing/remitting form of multiple sclerosis poorly responsive to conventional treatment, achieving a stabilization of the disease. In a double-blind placebo-controlled trial in 1999, Rostami et al. [85] found no significant differences in 16 patients with chronic progressive multiple sclerosis treated monthly with ECP (two ECP/ month) for 1 year (on-line technique, with oral administration of 8-MOP) [85]. These findings prompted further investigations in animal models [86-87] which subsequently resulted in two published pilot studies. In 2002, Chabannes et al. [88] showed only a transient response to ECP in 5 patients with chronic progressive multiple sclerosis, treated with off-line method; each patient received 15-19 ECPs over a 6-month period. All these patients relapsed or worsened after discontinuation of ECP. In 2006, Cavaletti et al. [9] reported on a pilot study performed in 5 patients with relapsing/remitting multiple sclerosis, resistant/refractory to conventional treatments, including steroids, IFN- $\beta$ and azathioprine. ECP treatment schedule included one procedure every 2 weeks for 4 months, followed by one procedure/month for the first year. In the second year the patients were given one ECP every 2 months as maintenance. During the first year of treatment 4 out of 5 patients showed a decreased relapse rate (3 with no relapses); during the second year, even the 5th patient improved; all patients showed an improvement of the extended disability score scale and a stabilization of central nervous system lesions at magnetic resonance imaging. After discontinuation of treatment, the positive effect lasted $>1$ year. The different impact of ECP in patients with multiple sclerosis, as reported in quoted studies, may reflect different selection criteria, in particular: stage of the disease (chronic progressive vs. relapsing/ remitting) and treatment length and schedule. Multiple sclerosis is the most common disease of the central nervous system in young adults, and a large number of patients become resistant or refractory to conventional treatment. HSCT has therefore been proposed in selected patients with subsequent transplant-related morbidity and mortality [89], but as ECP is not accompanied by severe side effects and is usually well tolerated, the possible effectiveness of ECP in this particular disease certainly merits further investigation. 
In 1989 Perez et al. [90] showed that syngeneic UVA-treated lymphocytes in presence of 8-MOP down-regulated host responsiveness to foreign MHC antigens in an animal model. In 1992 Costanzo-Nordin et al. [91] reported on the usefulness of ECP in reversing moderate rejection after heart allograft, as shown histologically by the reduction of mononuclear cell infiltrate in myocardial tissues. In 1998 Barr et al. [92] reported the results of a prospective randomized multicenter trial performed in 60 patients randomly assigned to receive standard triple-drug immunosuppressive treatment alone or in conjunction with ECP (a total of 24 procedures over a 6-month period). The frequency of patients with $0-1$ rejection episodes was higher among those who underwent ECP compared to the control group ( 82 vs. $52 \%$ ).

As a result, ECP was adopted in several different organ transplantation settings, as reported by Dall'Amico et al. [93]. An intensified ECP regimen (two procedures every 2 weeks) induced a favorable response in patients with renal allograft rejection unresponsive to conventional immunosuppressive treatment [94]. Moreover, Dall'Amico et al. [95] reported a positive response to ECP in 7 out of 10 patients with recurrent/refractory rejection after renal transplant. At 2-5 years follow-up, all 7 responders remained rejection free, and no increase in the infection rate was observed. There are only a few published reports regarding the use of ECP in the lung transplant setting since the first ones published by Slovis et al. [96] in 1995 and Salerno et al. [97] in 1999 on 3 and 8 patients, respectively. These studies showed that patients with lung rejection and grade $0-1$ bronchiolitis obliterans improved after ECP performed at monthly intervals. Diversely, Villanueva et al. [98] and Astor et al. [99] showed that patients with grade 2-3 bronchiolitis obliterans do not usually benefit from ECP. Finally, very few papers have been published about the possible effectiveness of ECP in the liver transplantation setting. In 2004, Urbani et al. [100] reported on 5 patients transplanted for $\mathrm{HBV}$ and/or HCV cirrhosis with biopsy-proven rejection in spite of conventional immunosuppressive treatment including calcineurin inhibitors. After a median of $20 \mathrm{ECP}$ procedures and a median follow-up of 8 months, neither rejection relapses nor $\mathrm{HBV} / \mathrm{HCV}$ recurrence were observed. The same investigators recently reported on a possible role of ECP in avoiding/reducing the use of calcineurin inhibitors in patients undergoing liver transplant and at high risk of renal or neurological complications [101]. They investigated survival at 1, 6 and 12 months after liver transplantation and observed a more favorable trend in the ECP-treated group when compared to controls $(94.4,88.1$ and $88.1 \%$ vs. $94.4,77.7$ and $72.2 \% ; \mathrm{p}<0.001)$.

\section{Future Perspectives}

In 2001 Berger et al. [102] reported very interesting findings concerning the modification of standard ECP procedures, including overnight incubation of the collected and irradiated MNC instead of infusing the product into the patient immediately after irradiation. They observed that immature, monocyte-derived, CD36+ CD83+ dendritic cells were strongly phagocytic against malignant $\mathrm{T}$ cells and were able to stimulate significant proliferation of normal lymphocytes against malignancy. These investigators defined this new approach as 'transimmunization' [19, 31]. Girardi et al. [103] reported on the first clinical experience with a favorable response achieved in the treatment of 2 patients with advanced CTCL, previously resistant to conventional ECP. All of these studies led to the start of an open-label phase I clinical trial, the results of which were published in 2006 [104]. In 27 patients with CTCL, transimmunization was applied monthly for 3-5 months alone or in combination with electron beam therapy. A significant mean reduction of both infiltrative skin lesions (in $55 \%$ of 20 patients) and malignant circulating $\mathrm{T}$ cells (reduced by $50 \%$ in 12 leukemic patients) was observed, with no clinically relevant side effects. Thus, transimmunization should be considered a natural evolution of ECP, widening its clinical applicability even in the field of malignant disease, where an adequate number of tumor-specific dendritic cells might be generated without the need for a GMP facility, provided that appropriate quality controls are applied to enhance product safety as recently reported [105].

\section{Conclusions}

ECP has seen an impressive diffusion worldwide since its first applications in CTCL patients. Nevertheless, as above reported several questions still remain to be answered - mainly about its real mechanism of action, the optimal treatment schedule and when and in which patients/diseases this technique should be adopted. Furthermore, ECP itself has some limitations: it requires dedicated devices (at least if the on-line technique is adopted); it is a long-lasting, time-consuming treatment which needs suitable venous accesses or the placement of central venous catheters and it is not cheap. There is general agreement about its usefulness in several clinical settings, and in at least in one (CTCL) ECP has received formal authorization from the FDA in the USA. Unfortunately, recognition by national health authorities in Europe (and subsequent re-imbursement), is still compromised by the lack of large randomized multicenter studies, thus excluding many patients from a potentially effective treatment.

It is my opinion that ECP is a powerful tool and that we are still learning the best ways to use it. I also believe that it is time to set up a strong and fruitful cooperation between those centers which currently perform ECP, to design multicenter 
trials which aim to ascertain the real effectiveness of ECP and the best way to apply it, and to ask for financial support from central national and/or European institutions avoiding any company interference.

\section{Acknowledgements}

I would greatly acknowledge Attilio Rovelli, MD from the Bone Marrow Transplantation Unit, Clinica Pediatrica-Università di Milano-Bicocca and Ospedale San Gerardo-Monza for his friendly advice and Mrs Joanna Upton for linguistic assistance.

\section{References}

1 Edelson R, Berger C, Gasparro F, Jegasothy B, Heald P, Wintroub B, Vonderheid E, Knobler R, Wolff K, Plewig G: Treatment of cutaneous T-cell lymphoma by extracorporeal photochemotherapy. N Engl J Med 1987;316:297-303.

2 Parrish JA, Fitzpatrick TB, Tannembaum L, Pathak MA: Photochemotherapy of psoriasis with oral methoxalen and long wavelength ultraviolet light. N Engl J Med 1974;29:1207-1211.

3 Heald P, Rook A, Perez MI, Wintroub B, Knobler R, Jegasothy B, Gasparro F, Berger C, Edelson R: Treatment of erythrodermic cutaneous T-cell lymphoma with extracorporeal photochemotherapy. J Am Acad Dermatol 1992;27:427-433.

4 Rook AH, Jegasothy BV, Heald P, Nahass GT, Ditre C, Witmer WK, Lazarus GS, Edelson R: Extracorporeal photochemotherapy for drug resistant pemphigus vulgaris. Ann Intern Med 1990;112: 303-305.

$\checkmark 5$ Rook AH, Freundlich B, Jegasothy BV, Perez MI, Barr WG, Jimenez SA, Rietschel RL, Wintroub B, Kahalen MB, Varga J: Treatment of systemic sclerosis with extracorporeal photochemotherapy. Results of a multicenter trial. Arch Dermatol 1992; 128:337-346.

6 de Misa RF, Azana JM, Harto A, Ledo A: Extracorporeal photochemotherapy in the treatment of severe psoriatic arthropathy. Br J Dermatol 1992; 127:448.

7 Menkes CJ, Andreu G, Heshmati F, Hilliquin P: Extracorporeal photochemotherapy Br J Rheumatol 1992;31:793-796.

$>8$ Reinisch W, Nahavandi H, Santella R, Zhang Y, Gasche C, Moser G, Waldhor T, Gangl A, Vogelsang H, Knobler R: Extracorporeal photochemotherapy in patients with steroid dependent Crohn's disease: a prospective pilot study. Aliment Pharmacol Ther 2001;15:1313-1322.

-9 Cavaletti G, Perseghin P, Dassi M, Cavarreta R, Frigo M, Caputo D, Stanzani L, Tagliabue E, Zoia C, Grimaldi M, Isella V, Rota S, Ferrarese C, Frattola L: Extracorporeal photochemotherapy: a safety and tolerability pilot study with preliminary efficacy results in refractory relapsing-remitting multiple sclerosis. Neurol Sci 2006;27:24-32.

10 Costanzo Nordin MR, Hubbel EA, O’Sullivan RJ, Johnson MR, Mullen GM, Heroux AL, Kao WG: Photopheresis versus corticosteroids in the therapy of heart transplant rejection. Circulation 1992;86: 242-250.

11 Rossetti F, Dall'Amico R, Crovetti G, Messina C, Montini G, Dini G, Locatelli F, Argiolu F, Miniero R, Zacchello G: Extracorporeal photochemotherapy for the treatment of graft-versus-host disease. Bone Marrow Transplant 1996;18(suppl 2):175-181.

12 Schooneman F: Extracorporeal photopheresis technical aspects. Transfus Apher Sci 2003;28:51-61.

13 Andreu G, Leon A, Heshmati F, Tod M, Menkes CJ, Baudelot J, Laroche L: Extracorporeal photochemotherapy (ECP): evaluation of two techniques and use in connective tissues disorders. Transfus Sci 1994;15:443-454.
14 Salvaneschi L, Perotti C, Zecca M, Bernuzzi S, Viarengo G, Giorgiani G, Del Fante C, Bergamaschi P, Maccario R, Pession A, Locatelli F: Extracorporeal photochemotherapy for the treatment of acute and chronic GVHD in childhood. Transfusion 2001:41:1299-1305.

15 Perseghin P, Dassi M, Balduzzi A, Rovelli A, Bonanomi S, Uderzo C: Mononuclear cell collection in patients undergoing extra-corporeal photochemotherapy for acute and chronic graft-vs-host disease (GvHD): comparison between COBE Spectra version 4.7 and 6.0 (AutoPBSC) J Clin Apher 2002; 17:65-71.

16 Kanold J, Messina C, Halle P, Locatelli F, Lanino E, Cesaro S and Deméocq F, on behalf of the Paediatric Diseases Working Party of the European Group for Blood and Marrow Transplantation (EBMT): Update on extracorporeal photochemotherapy for graft-versus-host disease treatment. Bone Marrow Transplant 2005;35:S69-S71.

17 Perseghin P, Galimberti S, Balduzzi A, Bonanomi S, Baldini V, Rovelli A, Dassi M, Rambaldi A, Castagna L, Corti P, Pogliani EM, Uderzo C: Extracorporeal photochemotherapy for the treatment of chronic graft-versus-host disease: trend for a possible cell dose-related effect? Ther Apher Dial 2007; 11:85-93.

18 Valbonesi M: International Forum: Italy. What's going on in Italy at the end of 2004. Transfus Apher Sci 2005;32:129-132.

19 Edelson RL: Transimmunization: science catches up to the clinical success. Transfus Apher Sci 2002; 26:177-180.

20 Heshmati F: Mechanisms of action of extracorporeal photochemotherapy. Transfus Apher Sci 2003;29: 61-70.

21 Taylor A, Gasparro FP: Extracorporeal photochemotherapy for cutaneous T-cell lymphoma and other diseases. Semin Hematol 1992;29:132-141.

22 Bladon J, Taylor PC: Extracorporeal photopheresis induces apoptosis in the lymphocytes of cutaneous T-cell lymphoma and graft-versus-host disease patients. Br J Haematol 1999;107:707-711.

23 Tambur AR, Ortegel JW, Morales A, Klingeman H, Gebel HM, Tharp MD: Extracorporeal photopheresis induces lymphocyte but not monocyte apoptosis. Transplant Proc 2000;32:747-748.

24 Bladon J, Taylor PC: Early reduction in the number of $\mathrm{T}$ cells producing pro-inflammatory cytokines, observed after extracorporeal photopheresis, is not linked to apoptosis induction. Transplant Proc 2003; 35:1328-1332.

25 Bladon J, Taylor PC: Extracorporeal photopheresis in cutaneous T-cell lymphoma and graft-versus-host disease induces both immediate and progressive apoptotic processes. Br J Dermatol 2002;146:59-68.

26 Bladon J, Taylor PC: Lymphocyte treated by extracorporeal photopheresis can down-regulate cytokine production in untreated monocytes. Photoderm Photimmunol Photomed 2005;21:293-302.
27 Bladon J, Taylor PC: Extracorporeal photopheresis: a focus on apoptosis and cytokines. J Dermatol Sci 2006;43:85-94.

28 Rigolio R, Perseghin P, Jonsson S, Petersson J, Cavaletti G, Cilio CM: A new device to study ex-vivo the effects of extracorporeal photochemotherapy on the immune system. J Photochem Photobiol (B) 2007;88:68-75.

29 Foss FM, Gorgun G, Miller KB: Extracorporeal photopheresis in chronic graft-versus-host diseases. Bone Marrow Transplant 2002;29:719-725.

30 Marshall SR: Technology insight: ECP for the treatment of GvHD - can we offer selective immune control without generalized immunosuppression? Nature Oncol 2006;3:302-314.

31 Berger CL, Hanlon D, Kanada D, Girardi M, Edelson RL: Transimmunization: a novel approach for tumor immunotherapy. Transfus Apher Sci 2002; 26:205-216.

32 Zouboulis CC, Schmuth M, Doepfmer S, Dippel E, Orfanos CE: Extracorporeal photopheresis of cutaneous T-cell lymphoma is associated with reduction of peripheral blood CD4+ T lymphocytes. Dermatology 1998;196:305-308.

33 Di Renzo M, Rubegni P, De Aloe G, Paulesu L, Pasqui AL, Andreassi L, Auteri A, Fimiani M: Extracorporeal photochemotherapy restores $\mathrm{Th} 1 / \mathrm{Th} 2$ imbalance in patients with early stage cutaneous Tcell lymphoma. Immunology 1997;92:99-103.

34 Zeiser R, Marks R, Bertz H, Finke J: Immunopathogenesis of acute graft-versus-host disease: implications for novel preventive and therapeutic strategies. Ann Hematol 2004;83:551-565.

35 Vogelsang GB, Higman MA: Chronic graft versus host disease. Br J Haematol 2004;125:435-454.

36 Zorn E, Kim HT, Lee SJ, Floyd BH, Litsa D, Arumugarajah S, Bellucci R, Alyea EP, Antin JH, Soiffer RJ, Ritz J: reduced frequency of FoxP3+ CD4+ $\mathrm{CD} 25+$ regulatory $\mathrm{T}$ cells in patients with chronic graft-versus-host disease. Blood 2005;106:2903-

2911.
37 Hess AD: Modulation of graft-versus-host disease: role of regulatory T lymphocytes. Biol Blood Marrow Transplant 2006;12:13-22.

38 Le NT, Chao N: Regulating regulatory T cells. Bone Marrow Transplant 2007;39:1-9.

39 Alcindor T, Gorgun G, Miller KB, Roberts TF, Sprague K, Schenkein DP, Foss FM: Immunomodulatory effects of extracorporeal photochemotherapy in patients with extensive chronic graft-versushost disease. Blood 2001;98:1622-1625.

40 Gorgun G, Miller KB, Foss FM: Immunologic mechanism of extracorporeal photochemotherapy in chronic graft-versus-host disease. Blood 2002; 100:941-947.

41 Lamioni A, Parisi F, Isacchi G, Giorda E, Di Cesare S, Landolfo A, Cenci F, Bottazzo GF, Carsetti R: The immunological effects of extracorporeal photopheresis unraveled: induction of tolerogenic dendritic cells in vitro and regulatory $\mathrm{T}$ cells in vivo. Transplantation 2005;79:846-850. 
42 Biagi E, Di Biaso I, Leoni V, Gaipa G, Rossi V, Bugarin C, Renoldi G, Parma M, Balduzzi A, Perseghin P, Biondi A: Extracorporeal photochemotherapy is accompanied by increasing levels of circulating CD4+ CD25 +GITR+ FoxP3+ $\mathrm{CD} 62 \mathrm{~L}+$ functional regulatory $\mathrm{T}$-cells in patients with graft-versus-host disease. Transplantation 2007;84:31-39.

43 Lim HW, Edelson RL: Photopheresis for the treatment of cutaneous T-cell Lymphoma. Hematol Oncol Clin North Am 1995;9:1117-1124.

44 Crovetti G, Carabelli A, Berti E, Guizzardi M, Fossati S, De Filippo C, Bertani E: Photopheresis in cutaneous T-cell lymphoma: a five-year experience. Int J Artif Organs 2000;23:55-62.

$\checkmark 4$ Evans AV, Wood BP, Scarisbrick JJ, Fraser-Andrews EA, Chinn S, Dean A, Watkins P, Whittaker SJ, Russell-Jones R: Extracorporeal photopheresis in Sézary syndrome: hematologic parameters as predictor of response. Blood 2001;98:1298-1301.

46 Knobler R, Jantschitsch C: Extracorporeal photochemoimmunotherapy in cutaneous T-cell lymphoma. Transfus Apher Sci 2003;28:81-89.

47 Schreiner T, Gaczkowski A, Scharffetter-Kocanek $\mathrm{K}$, Borberg H: Small-scale extracorporeal photopheresis for the treatment of cutaneous T-cell lymphoma: a report of 3 cases. Transfus Apher Sci 2005;32:197-203.

48 Rook AH, Jegasothy BV, Heald P, Nahass GT, Ditre C, Wilmer WK, Lazarus GS, Edelson RL: Extracorporeal photochemotherapy for drug-resistant pemphigus vulgaris. Ann Intern Med 1990;112: 303-305.

49 Gollnick HP, Owsianowski M, Taube KM, Orfanos CE: Unresponsive severe generalized pemphigus vulgaris successfully controlled by extracorporeal photopheresis. J Am Acad Dermatol 1993;28:122124.

50 Wollina U, Lange D, Looks A: Short-time extracorporeal photochemotherapy in the treatment of drug-resistant autoimmune bullous diseases. Dermatology 1999;198:140-144.

51 Gordon KB, Chan LS, Woodley DT. Treatment of refractory epidermolysis bullosa acquisita with extracorporeal photochemotherapy. Br J Dermatol 1997;136:415-420.

$\checkmark 52$ Bécherel PA, Bussel A, Chosidow O, Rabian C, Piette JC, Francès C: Extracorporeal photochemotherapy for chronic erosive lichen planus. Lancet 1998;351:805.

-53 Sand M, Bechara FG, Sand D, Radenhausen M, Tomi NS, Altmeyer P, Hoffmann K: Extracorporeal photopheresis as a treatment for patients with severe, refractory atopic dermatitis. Dermatology 2007;215:134-138.

-54 Messina C, Locatelli F, Lanino E, Uderzo C, Zacchello C, Cesaro S, Pillon M, Perotti C, Del Fante C, Faraci M, Rivabella L, Calore E, De Stefano P, Zecca M, Giorgiani G, Brugiolo A, Balduzzi A, Dini G, Zanesco L, Dall'Amico R: Extracorporeal photochemotherapy for paediatric patients with graft-versus-host diesease after haematopoietic stem cell transplantation. Br J Haematol 2003;122: 118-127.

-55 Zecca M, Prete A, Rondelli R, Lanino E, Balduzzi A, Messina C, Fagioli F, Porta F, Favre C, Pession A, Locatelli F: Chronic graft-versus-host disease in children: incidence, risk factors, and impact on outcome. Blood 2002;100:1192-1200.

56 Owsianowsky M, Gollnick H, Siegert W, Schwerdtfeger R, Orfanos CE: Successful treatment of chronic graft-versus-host disease with extracorporeal photopheresis. Bone Marrow Transplant 1994; 14:845-848.
7 Rossetti F, Zulian F, Dall'Amico R, Messina C, Montini G, Zacchello F: Extracorporeal photochemotherapy as single therapy for estensive, cutaneous chronic graft-versus-host disease. Transplantation 1995;59:149-151.

58 Schooneman F, Claise C: Treatment of graft versus host disease (GVHD) by photopheresis? Transfus Sci 1997; 17:527-536.

59 Greinix HT, Volc-Platzer B, Rabitsch W, Gmeinhart B, Guevara-Pineda C, Kahls P, Krutmann J, Hönigsmann H, Clovica M, Knobler RM: Successful use of extracorporeal photochemotherapy in the treatment of severe acute and chronic graft-versus-host disease. Blood 1998;92:3098-3104.

60 Sniecinsky I: Photochemotherapy for GvHD. Int J Artif Organs 2000;1:1-10.

61 Perotti C, Torretta L, Viarengo G, Riveda L, Bernuzzi S, Carbone S, Del Fante C, La Torre R, Locatelli F, Sonetti F, Gabba P, Bellosta M, Salvaneschi L: Feasibility and safety of a new technique of extracorporeal photochemotherapy: experience of 240 procedures. Haematologica 1999;84: 237-241.

62 Kanold J, Paillard C, Halle P, D'Incan M, Bordigoni P, Deméocq F: Extracorporeal photochemotherapy for graft versus host disease in pediatric patients Transfus Apher Sci 2003;28:71-80.

63 Apisarnthanarax N, Donato M, Körbling M,Couriel D, Gajewski J, Giralt S, Khouri I, Hosing C, Champlin R, Duvic M, Anderlini P: Extracorporeal photopheresis therapy in the management of steroidrefractory or steroid-dependent cutaneous graftversus-host disease after allogeneic stem cell transplantation: feasibility and results. Bone Marrow Transplant 2003;31:459-465.

64 Biagi E, Perseghin P, Buscemi F, Dassi M, Rovelli A, Balduzzi A: Effectiveness of extracorporeal photochemotherapy in treating long-term refractory chronic graft-versus-host disease. Haematologica 2000;85:329-330.

65 Akpek G, Lee SJ, Flowers ME, Pavletic SZ, Arora M, Lee S, Piantadosi S, Guthrie K, Lynch JC, Takatu A, Horowitz MM, Antin JH, Weisdorf DJ, Martin PJ, Vogelsang GB: Performance of a new clinical grading system for chronic graft-versushost disease: a multicenter study. Blood 2003;102: 802-809.

66 Pavletic SZ, Lee SJ, Socie G, Vogelsang G: Chronic graft-versus-host disease: implications of the $\mathrm{Na}-$ tional Institutes of Health consensus development project on criteria for clinical trials. Bone Marrow Transplant 2006;38:645-651.

67 Pavletic SZ, Martin P, Lee SJ, Mitchell S, Jacobson D, Cowen EW, Turner ML, Akpek G, Gilman A, McDonald G, Schubert M, Berger A, Bross P, Chien JW, Couriel D, Dunn JP, Fall-Dickson J, Farrell A, Flowers MED, Greinix HT, Hirschfeld S, Gerber L, Kim S, Knobler R, Lachenbruch PA, Miller FW, Mittleman B, Papadopoulos E, Parsons SK, Przepiorka D, Robinson M, Ward M, Reeve B, Rider LG, Shulman H, Schultz KR, Weisdorf D, Vogelsang GB: Measuring therapeutic response in chronic graft-versus-host disease: NIH consensus development project on criteria for clinical trials in chronic GvHD: IV. Response criteria working group report. Biol Blood Marrow Transplant 2006;12:252-266.

68 Foss FM, DiVenuti GM, Chin K, Sprague K, Grodman H, Klein A, Chan G, Stiffler K, Miller KB: Prospective study of extracorporeal photopheresis in steroid-refractory or steroid-resistant extensive chronic graft-versus-host disease: analysis of response and survival incorporating prognostic factors. Bone Marrow Transplant 2005;35:1187-1193.
69 Couriel D, Hosing C, Saliba R, Shpall EJ, Anderlini P, Rhodes B, Smith V, Khouri I, Giralt S, de Lima M, Hsu I, Ghosh S, Neumann J, Andersson B, Qazilbash M, Hymes S, Kim S, Champlin R, Donato M: Extracorporeal photochemotherapy for the treatment of steroid-resistant chronic GvHD. Blood 2006;107:3074-3080

70 Garban F, Drillat P, Makowski C, Jacob MC, Richard MJ, Favrot M, Sotto JJ, Bensa JC, Cahn JY: Extracorporeal chemophototherapy for the treatment of graft-versus-host disease: hematologic consequences of short-term, intensive courses. Haematologica 2005;90:1096-1101.

71 Greinix HT, Knobler RM, Worel N, Schneider B, Schneeberger A, Hoecker P, Mitterbauer M, Rabitsch W, Schulenburg A, Kahls P: The effect of intensified extracorporeal photochemotherapy on long term survival in patients with severe acute graft-versus-host disease. Haematologica 2006;91: 405-408.

72 Lee SJ: New approaches for preventing and treating chronic graft-versus-host disease. Blood 2005; 105:4200-4206.

73 Rook A, Freundlich N, Nahass GT, Washko R, Macelis B, Skolnicki M, Bromley P, Witmer WK, Jegasothy BV: Treatment of autoimmune disease with extracorporeal photochemotherapy: progressive systemic sclerosis. Yale J Biol Med 1989;62:639_ 645.

74 Rook A, Freundlich N, Jegasothy BV, Perez MI, Barr WG, Jimenez SA, Riestchel RL, Wintroub B, Bashar Kahaleh M, Varga J, Heald PW, Steen V, Massa MC, Murphy GF, Perniciaro C, Istfan M, Ballas SK, Edelson RL: Treatment of systemic sclerosis with extracorporeal photochemotherapy. Arch Dermatol 1992;128:337-346.

75 Zachariae H, Bjerring P, Heickendorff L, Møller B, Wallevik K, Angelo H: Photopheresis in systemic sclerosis: clinical and serological studies using markers of collagen metabolism. Acta Derm Venereol 1993;73:356-361.

76 Knobler RM, French LE, Kim Y, Bisaccia E, Graninger W, Nahavandi H, Strobl FJ, Keystone E, Mehlmauer M, Rook AH, Braverman I: Systemic sclerosis study group. A randomized double-blind, placebo controlled trial of photopheresis in systemic sclerosis. J Am Acad Dermatol 2006;54: 793-799.

77 Malawista SE, Trock DH, Edelson RL: Treatment of rheumatoid arthritis by extracorporeal photochemotherapy. Arthritis Rheum 1991;34:646-653.

78 Menkes CJ, Andreu G, Heshmati F, Hilliquin P: Treatment of refractory rheumatoid arthritis by extracorporeal photochemotherapy. Br J Rheumatol 1992;31:789-790.

79 Wilfert H, Honigsmann H, Steiner G, Smolen J, Wolff K: Treatment of psoriatic arthritis by extracorporeal photochemotherapy. Br J Dermatol 1990; 122:225-232.

80 de Misa RF, Azana JM, Harto A, Boixeda P, Moreno L, Ledo A: Psoriatic arthritis: one year of treatment with extracorporeal photochemotherapy. J Am Acad Dermatol 1994;30:1037-1038.

81 Knobler RM, Graninger W, Lindmaier A: Extracorporeal photochemotherapy for the treatment of systemic lupus erythematosus. A pilot study. Arthritis Rheum 1992;35:319-324.

82 Hafler DA, Weiner HL: T cells in multiple sclerosis and inflammatory central nervous system disease. Immunol Rev 1987;100:307-332.

83 Wekerle H, Kojima K, Lannes V, Vieira J, Lassmann H, Limìnington C: Animal models. Ann Neurol 1994;36:47-53. 
84 Poehlau D, Rieks M, Postert T, Westernhausen R, Busch S, Hoffmann K, Altmeyer P, Przuntek H: Photopheresis - a possible treatment of multiple sclerosis? Report of two cases. J Clin Apher 1997; 12:154-155.

85 Rostami AM, Sater RA, Bird SJ, Galetta S, Farber RE, Kamoun M, Silberberg DH, Grossman RI, Pfohl D: A double-blind, placebo-controlled trial of extracorporeal photopheresis in chronic progressive multiple sclerosis. Mult Scler 1999;5:198-203.

86 Cavaletti G, Perseghin P, Dassi M, Oggioni N, Sala F, Lolli F, Riccio P, Tredici G, Frattola L: Extracorporeal photochemotherapy reduces the incidence of relapses in experimental allergic encephalomyelitis in DA rats. J Neurol 2001;248:535-536.

87 Chabannes D, Besnier DP, Esnault VLM: Photopheresis affects the course of experimental allergic encephalomyelitis in Lewis rat. Photodermatol Photoimmunol Photomed 2002;18:238-243.

88 Besnier DP, Chabannes D, Mussini JMG, Dupas B, Esnault VLM: Extracorporeal photochemotherapy for secondary chronic progressive multiple sclerosis: a pilot study. Photodermatol Photoimmunol Photomed 2002;18:36-41.

89 Kapoor S, Wilson AG, Sharrack B, Lobo A, Akil M, Sun L, Dalley CD, Snowden JA: Haemopoietic stem cell transplantation - an evolving treatment for severe autoimmune and inflammatory disease in rheumatology, neurology and gastroenterology. Hematology 2007;12:179-191.

90 Perez M, Edelson RL, Laroche L, Berger C: Inhibition of anti-skin allograft immunity by infusions with syngeneic photo-inactivated effector lymphocytes. J Invest Dermatol 1898;92:669-676.
91 Costanzo-Nordin MR, Hubbell E, O’Sullivan EJ, Johnson MR, Mullen GM, Heroux AL, Kao WG, Mcmanus BM, Pifarre R, Robinson J: Successful treatment of heart transplant rejection with photopheresis. Transplantation 1992:53:808-815.

92 Barr ML, Meiser BM, Eisen HJ, Roberts RF, Livi U, Dall'Amico R, Dorent R, Rogers JG, Radovanevic B, Taylor DO, Jeevanandam V, Marboe CC: Photopheresis for the prevention of rejection in cardiac transplantation. N Engl J Med 1998;339: 1744-1751.

93 Dall'Amico R, Murer L: Extracorporeal photochemotherapy: a new therapeutic approach for allograft rejection. Transfus Apher Sci 2002;26: 197-204.

94 Sunder-Plassman G, Druml W, Steininger R, Hönigsmann H, Knobler R: Renal allograft rejection controlled by photopheresis. Lancet 1995: 346:506.

95 Dall'Amico R, Murer L, Montini G, Andreetta B, Zanon GF, Zacchello G, Zacchello F: Successful treatment of recurrent rejection in renal transplant patients with photopheresis. J Am Soc Nephrol 1998;9:121-127.

96 Slovis BS, Loyd J, King LE: Photopheresis for chronic rejection of lung allografts. N Engl J Med 1995;332:962.

97 Salerno CT, Park SJ, Kreykes NS, Kulick DM, Savik K, Hertz MI, Bolmann RM: Adjuvant treatment of refractory lung transplant rejection with extracorporeal photopheresis. J Thorac Cardiovasc Surg 1999;117:1063-1069.

98 Villanueva J, Bhorade SM, Robinson JA, Husain AN, Garrity ER: Extracorporeal photopheresis for the treatment of lung allograft rejection. Ann Transplant 2000;5:44-47.
99 Astor TL, Weill D: Extracorporeal photopheresis in lung transplantation. J Cut Med Surg 2003;7:20-24

100 Urbani L, Mazzoni A, Catalano G, De Simone P, Vanacore R, Pardi C, Bortoli M, Biancofiore G, Campani D, Perrone V, Mosca F, Scatena F, Filipponi F: The use of extracorporeal photopheresis for allograft rejection in liver transplant recipients. Transplant Proc 2004;36:3068-3070.

101 Urbani L, Mazzoni A, De Simone P, Catalano G, Coletti L, Petruccelli L, Biancofiore G, Bindi L, Scatena F, Filipponi F: Avoiding calcineurin inhibitors in the early post-operative course in highrisk liver transplant recipients: the role of extracorporeal photopheresis. J Clin Apher 2007;22: 187-194.

102 Berger C, Xu A, Hanlon D, Lee C, Schechner J, Glusac E, Christensen I, Snyder E, Holloway V, Tigelaar R, Edelson RL: Induction of human tumor-loaded dendritic cells. Int J Cancer 2001;91: 438-447.

103 Girardi M, Schechner J, Glusac E, Berger C, Edelson RL: Transimmunization and the evolution of extracorporeal photochemotherapy. Transfus Apher Sci 2002;26:181-190.

104 Girardi M, Berger CL, Wilson LD, Christensen IR, Thompson KR, Glusac EJ, Edelson RL: Transimmunization for T cell lymphoma: a phase I study. Leuk Lymphoma 2006;47:1495-1503.

105 Bredberg A, Jonsson S, Lindblom A, Björk P: Clinical-scale generation of strongly CD83-expressing dendritic cells using extracorporeal photopheresis. Photodermatol Photoimmunol Photomed 2007;23:113-119. 